\title{
Comparing the anti-inflammatory effects of Simvastatin and Rosuvastatin by measuring IL-1 $\beta$, IL-6 and TNF- $\alpha$ levels using a murinic caecal ligation and puncture induced sepsis model
}

\section{Compararea efectelor anti-inflamatoare ale Simvastatinei și Rosuvastatinei măsurând nivelele serice ale IL-1 $\beta$, IL-6 si TNF- $\alpha$ folosind un model de sepsis la șobolan indus prin ligatură și puncție cecală}

\author{
Mihai Mărginean $\mathrm{M}^{1, \text { a }}$, Sebastian Trancăa, a, , Alina Ardelean-Maghiar \\ (Mărginean) 3, a , Dan Dîrzu², Adina Huţanu ${ }^{4}$, Oana Platon (Antal) ${ }^{2}$, Dan \\ Dobreanu $^{1}$ \\ 1. Physiology Department, University of Medicine and Pharmacy of Tîrgu-Mureș, Romania. \\ 2. Department of Anaesthesia and Intensive Care, University of Medicine and Pharmacy \\ "Iuliu Hațieganu” Cluj-Napoca, Romania \\ 3. Clinical Laboratory, Emergency Military Hospital "Dr. Constantin Papilian”, Cluj-Napoca, Romania. \\ 4. University of Medicine and Pharmacy of Tîrgu-Mureș.
}

\begin{abstract}
Background: Sepsis is a systemic host response to an infection which may evolve into severe sepsis and septic shock. It raises many health care related concerns around the world, carrying almost $30 \%$ mortality rates and a high financial burden. The disease is characterized by the triggering of some inflammatory pathways that are ultimately proven deleterious to the host organism. Although antibiotics, fluid administration, vasopressor therapy and infectious source control remain the recommended management strategies, emerging scientific data proposes statins as a new line of treatment. These drugs were first introduced in clinical practice for their cholesterol-lowering effect but the inhibition of HMG-CoA reductase and cholesterol biosynthetic pathway exhibits some less studied effects generally referred to as pleiotropic: anti-inflammatory, antithrombotic, immunomodulatory and antioxidant properties. Objective: To asses and compare the anti-inflammatory effect of two statins - Simvastatin and Rosuvastatin - measuring blood levels of IL-1 $\beta$, IL-6 and TNFa using a previously described murinic model of sepsis. Methods: We compiled four groups (C, $n=7 ;$; SEP, SV, RV, $n=8)$. Statins were administered in two doses 18 and 3 hours before surgical intervention. Sepsis was induced using the caecal ligation and puncture technique. Blood samples were obtained by venepuncture from each subject in day 1, 4, 7 and 14 (the last samples were obtained by cardiac puncture). Complete blood count, Procalcitonin, IL-1 $\beta, I L-6$ and TNF- $\alpha$ levels were assessed. Results: White blood cell counts differed across the groups showing a higher count for the septic but untreated group. Procalcitonin reacted in all septic groups but both statin treated groups had lower levels when compared to untreated group. IL-1 levels were higher in the Rosuvastatin treated group. IL-6 levels were more heterogeneously
\end{abstract}

*Corresponding author: Sebastian Trancă, Department of Anaesthesia and Intensive Care, Cluj-Napoca, Romania; e-mail: tranca.sebastian@gmail.com

a These authors contributed equally to this work. 
dispersed but higher levels were noticed in the untreated septic group. The Simvastatin treated group had higher levels compared to the Rosuvastatin treated one. TNFa levels were higher in the septic untreated group and in the Rosuvastatin treated one. For the Simvastatin treated subjects, the level of TNFa was similar with the control group. Conclusion: We concluded that both drugs showed anti-inflammatory effects on the murinic CLP-induced sepsis model. Between the two, Simvastatin had greater impact by lowering blood levels of established pro-inflammatory markers.

Keywords: sepsis; experimental model; rat; HMG-CoA reductase; Simvastatin; Rosuvastatin; interleukins; cytokines.

\section{Rezumat}

Introducere: Sepsisul este o boala caracterizată printr-un răspuns sistemic inflamator cauzat o infecție care poate evolua către sepsis sever și şoc septic. Această patologie ridică mari probleme la nivel global din cauza mortalității ridicate (care în anumite situații atinge 30\%) precum și din cauza încarcăturii financiare mari. Sepsisul se caracterizează prin declasnșarea unor căi imune pro-inflamatorii cu rol de apărare a organismului dar care ulterior se dovedesc a fi extrem de dezajantajoase. Deși antibioterapia, resuscitarea volemică, terapia vasopresoare şi controlul sursei de infecție rămân strategiile recomandate în tratamentul sepsisului, date publicate recent propun statinele ca o noua linie de tratament. Aceste medicamente au fost introduse în practica clinică datorită efectului hipocolesterolemiant însă inhibarea reductazei $\mathrm{HMG}-\mathrm{CoA}$ și a biosintezei colesterolului induce o serie de efecte mai putin studiate denumite generic pleiotrope: anti-inflamatoare, antitrombotice, imunomodulatoare și antioxidante. Obiective: În cadrul acestui experiment ne-am propus să evaluăm și să comparăm efectul antiinflamator al Simvastatinei și Rosuvastatinei măsurând nevelele serice ale IL-1 $\beta$, IL- 6 și TNF- $\alpha$ folosind un model consacrat de sepsis la şobolan. Metode: Am alcătuit patru grupuri (C, $n=7 ; S E P, S V, R V, n=8)$. Statinele au fost administrate în două doze cu 18 și 3 ore inaintea intervenției chirurgicale. Sepsisul a fost obținut prin tehnica ligaturării și puncției cecale. De la fiecare subiect au fost recoltate eșantioane de sânge prin puncție venoasă in zilele 1, 4, 7 și 14 (ultimele eșantioane au fost obținute prin puncție cardiacă). Au fost analizați următorii parametrii: hemoleucograma, Procalcitonina, IL-1B, IL-6 și TNF- $\alpha$. Rezultate: Numărul total al leucocitelor a fost mai mare pentru grupul septic dar netratat. Procalcitonina a fost reacționată în toate grupurile septice însă valori mai mici au fost observate în grupurile tratate cu Simvastatină și Rosuvastatină în comparație cu grupul netratat. Nivelul de IL-1 3 a fost mai mare în grupul tratat cu Rosuvastatină. Nivelele de IL-6 au avut o dispersie heterogenă în cadrul experimentului însă au fost înregistrate niveluri mai înalte în cadrul grupului septic netratat. Grupul tratat cu Simvastatină a avut nivele serice mai mari comparativ cu grupul tratat cu Rosuvastatină. Nivelele de TNF- $\alpha$ au fost mai mari pentru grupul septic netratat și cel tratat cu Rosuvastatină. Pentru grupul tratat cu Simvastatină nivelele TNF- $\alpha$ a fost similare cu cele din grupul control. Concluzii: Ambele statine au efecte anti-inflamatorii în cadrul acestui model de sepsis la șobolan indus prin tehnica ligaturării și puncției cecale. Dintre cele două, Simvastatina a avut un impact mai mare prin scăderea nivelelor circulante a unor markeri proinflamatori consacrați.

Cuvinte cheie: sepsis; model experimental; şobolan; murinic; statine; reductază HMG-CoA; Simvastatină; Rosuvastatină; interleukine; citokine.

Received: $2^{\text {nd }}$ June 2014; Accepted: $21^{\text {st }}$ October 2014; Published: $22^{\text {nd }}$ October 2014.

\section{Introduction}

Sepsis is a systemic host response to an infection which may evolve into severe sepsis (sepsis-induced organ dysfunction or tissue hypoperfusion) and septic shock (severe sepsis with hypotension that is not reversed by fluid re- suscitation)(1). Severe sepsis and septic shock, in spite of medical and technological advances, remain one of the main concerns of health care providers around the World carrying almost $30 \%$ mortality rates and a high financial burden. (2) This disease is characterized by the triggering of 
some inflammatory pathways that are ultimately proven deleterious to the host organism by generating reactive oxygen species, inflammatory cytokines as well as nitric oxide production and antithrombin III depletion(3). Although antibiotics, fluid administration, restoring systemic vascular resistance with vasopressor therapy and infectious source control remain the main treatment options, emerging scientific data proposes the 3-hydroxy-3-methylglutaryl-coenzyme $A$ reductase (HMG-CoA reductase) inhibitors (or statins) as a new line of treatment. This class of drugs was first introduced in clinical practice for their cholesterol-lowering effect but the inhibition of HMG-CoA reductase and cholesterol biosynthetic pathway exhibits some less studied effects generally referred to as pleiotropic: the reduced expression of class II MHC (major histocompatibility complex), effects on cell signalling and consequent transcriptional level changes, inhibiting vascular smooth muscle growth, reducing vascular inflammation, the direct alteration of leukocyte-endothelial cell interaction, the induction of haem oxygenase, enhancing the stability of atherosclerotic plaques, beneficial effects on endothelial function and blood flow, decreasing LDL-C oxidation and modulating platelet aggregation $(4,5)$. These anti-inflammatory, antithrombotic, immunomodulatory and antioxidant properties were documented in a number of observational studies (6-14) but also in six large trials (15-20) with published results. In spite of the ongoing efforts of understanding these pleiotropic properties and establishing the role of statins in the management and treatment of the septic patient, there are only few authors that offer clear recommendations. Some of them concluded that statins may prove useful if administered before the onset of sepsis and during the resolution of this disease when the pro-inflammatory state of the host organism could be balanced by the anti-inflammatory properties of the statin therapy $(4,21)$. Others stated that established statin treatment should be continued because the cessation of such treatment is associated with worse survival rates (22). But the majority agree that more data is needed before a definitive conclusion may be drawn $(23,24)$. The main questions that still remain to be answered are witch statin is best for the septic patient, when should this be administered and what dose would be safe for this group of patients.

Our objective was to asses and compare the anti-inflammatory effect of two statins - Simvastatin and Rosuvastatin - measuring blood levels of Interleukin 1-beta (IL-1 $\beta$ ), Interleukin 6 (IL6) and Tumour Necrosis Factor - alpha (TNFa) using a previously described murinic model of sepsis (25-27). Given the fact that a previously established sepsis model was used, we did not include the whole array of parameters that would otherwise be needed to prove the presence of sepsis (1). Nonetheless, the parameters that were assessed for this experiment sustain the presence of sepsis for the groups inflicted with this disease, Procalcitonin level being the most important indicator (28-30).

\section{Material and Method}

\section{Subjects and group compiling}

We used 31 Wistar rats housed in a temperature controlled environment and fed under standard conditions (ad libitum standard rodent chow and water) with a 12 hour imposed sleep-wake cycle. They were randomized into four groups: control group (C, $n=7$ ), sepsis group (SEP, $n=8)$, sepsis+Simvastatin (SV, $n=8)$ and sepsis+Rosuvastatin $(\mathrm{RV}, n=8)$. For this experiment ethical committee approval has been obtained and European Union directives regarding the protection of animals used for scientific purposes were respected (31).

\section{Experimental protocol}

All animals were subjected to an 18-hour period of fasting prior to the first dose of statin. Food was then administered and a second period 
of fasting was employed before the second dose of statin. For the control group (C) the same periods of fasting were employed. They were anaesthetized using intraperitoneal Ketamine 100 $\mu \mathrm{g} / \mathrm{g}$ and Xylazine $10 \mu \mathrm{g} / \mathrm{g}$ (32). After induction of anaesthesia animals were placed under a heating lamp and a rectal probe was inserted for temperature monitoring. Fur was removed from abdomen and a sterile surgical field created. A 2 to $3 \mathrm{~cm}$ incision was made $1 \mathrm{~cm}$ left from the mid-line. After penetrating the abdominal cavity the caecum was identified and carefully extracted. For the control group (C) we performed a sham operation - the caecum was placed back inside the peritoneal cavity and the abdominal wall was closed in two layers using surgical sutures. For all other experimental groups we applied the caecal ligation and puncture technique (25-27). This consists of placing a tight ligature using nonresorbable suture $1 \mathrm{~cm}$ from the caecum base, distal from the ileo-caecal valve (without interrupting normal intestinal transit) and perforating it twice, on the same side, using a 19-gauge needle. Then the caecum is gently squeezed to extrude a small amount of faeces; this will initiate the septic process and also confirm that the puncture was efficient. The caecum is then replaced in the peritoneal cavity and sutures applied as described before. All animals were then resuscitated using pre-heated normal saline $(\mathrm{NaCl} 0.9 \%) 0.05 \mathrm{ml} / \mathrm{g}$ injected subcutaneously using a 26-gauge needle. This fluid resuscitation was repeated every 24 hours (33). Pain control was obtained using Tramadol 20 $\mu \mathrm{g} / \mathrm{g}$ every 24 hours subcutaneously, first dose being administered immediately after the operation. If the animal showed behavioural or clinical modifications consistent with inadequate analgesia (34-36) supplemental doses were given. For the statin groups (SV and RV) two oral doses of the drugs were administered 18 and 3 hours before induction of anaesthesia combined with usual standard food. The doses were $80 \mu \mathrm{g} / \mathrm{g}$
Simvastatin (37) or $20 \mu \mathrm{g} / \mathrm{g}$ Rosuvastatin. Until full recovery from anaesthesia was attained, the animals were monitored and normal body temperature assured. Monitoring continued for 14 days for each animal after which euthanasia was performed using intra-cardiac administration of a high dose of Sodium Pentobarbital (over 100 $\mathrm{mg} / \mathrm{kg})(38)$.

\section{Blood sampling}

While the animals were still under anaesthesia, we obtained blood samples by caudal vein puncture. Before attempting venepuncture the tail was submersed in $40{ }^{\circ} \mathrm{C}$ water for $10 \mathrm{~min}$ utes. A tourniquet was places at the base of the tail and a Heparine-flushed 23-gauge needle was used. After successful intra-vascular needle placement, blood was allowed to drip freely inside a commercially available capillary blood collector $\left(\mathrm{K}_{2}\right.$ EDTA coated tubes for complete blood count and standard plain tubes for cytokine and PCT testing). 1 to $2 \mathrm{ml}$ of blood was obtained during each phlebotomy session. For each animal we obtained three blood samples using the described method and a forth by cardiac puncture: the first immediately after the intervention (day 1), the second in day 4, third in day 7 and fourth in day 14. Each time anaesthesia was performed as described before. Total blood count was completed within 4 hours from the sampling and the rest of the blood was centrifuged, plasma was separated and kept at $-20{ }^{\circ} \mathrm{C}$ until further use.

\section{Laboratory testing}

We performed a complete blood count, Procalcitonin, IL-1 $\beta$, IL-6 and TNF- $\alpha$ plasma concentration measurements.

Blood cell analysis was performed using a Sysmex KX21-N automated haematology analyser. Cytokines and Procalcitonin (PCT) tests were made using commercially available readyto-use ELISA rat kits (KOMABIOTECH ${ }^{\circledR}$ for IL- 
6, IL-1beta and TNF- $\alpha$; Elabscience ${ }^{\circledR}$ for PCT).

For some of the samples we did not obtain the absolute value for cytokine concentration because the absorbance values could not be plotted. This is why all statistical analysis for IL-6, IL-1 $\beta$ and TNF- $\alpha$ was made using the absorbance values.

\section{Statistical analysis}

We compared the number of white blood cells (WBC), lymphocyte percentage (LYM\%), Procalcitonin (PCT), Interleukin 6 (IL-6), Interleukin 1-beta (IL-1 $\beta$ ) and Tumour Necrosis Factor alpha (TNF- $\alpha$ ) values, as follows: the control group (C) vs. sepsis group (SEP) at all four selected moments (day 1, 4, 7 and 14); the SEP group vs. sepsis+Simvastatin (SV) and SEP vs sepsis+Rosuvastatin (RV) at all moments; SV vs. RV at all moments. Student's t-test was employed and results presented as mean \pm standard deviation (SD). A $p$ value under 0.05 was considered significant. For statistical data management we used commercially available software (GraphPad Prism version 5.03 for Windows $\subseteq$, GraphPad Software, San Diego California USA, www.graphpad.com).

\section{Sepsis diagnosis}

We used Procalcitonin levels, white blood cell count, clinical observations (social behaviour, food and water intake, day-light activi- ty, general appearance) $(34,35)$ and body weight measurements. Also, as previously described (25-27), we initiated the septic process, after the caecal puncture, by extruding a small amount of faeces directly inside the peritoneal cavity.

\section{Results}

\section{White Blood Cells (WBC)}

When comparing $C$ group with SEP we obtained significant differences at all tested moments. Differences were also found between SEP and SV groups and SEP and RV ones (with two exceptions, SEP vs. SV, day 4 and SEP vs. RV, day 1). We did not find statistical differences between SV and RV groups in the first day but all other measurements differed significantly (Figure 1) (Table 1).

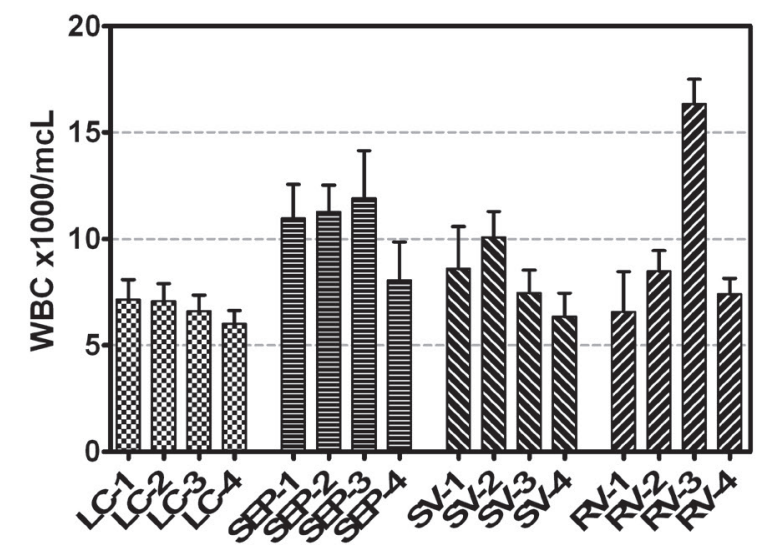

Figure 1. White blood cell count. (mean and SD)

Table 1. White blood cell counts and p values for statistical comparison across groups.

\begin{tabular}{ccccccccc}
\hline \multirow{2}{*}{ Day } & \multicolumn{3}{c}{ WBC $($ mean \pm SD $)$} & \multicolumn{5}{c}{ p value } \\
\cline { 2 - 8 } & C & SEP & SV & RV & C vs. SEP & SEP vs. SV & SEP vs. RV & SV vs. RV \\
\hline 1 & $7.2 \pm 0.93$ & $11.0 \pm 1.6$ & $8.6 \pm 2.0$ & $6.6 \pm 1.9$ & $<0.0001^{*}$ & $0.0199^{*}$ & $0.0002^{*}$ & 0.05 \\
\hline 4 & $7.1 \pm 0.82$ & $11.0 \pm 1.2$ & $10 \pm 1.2$ & $8.5 \pm 0.97$ & $<0.0001^{*}$ & 0.07 & $0.0002^{*}$ & $0.0114^{*}$ \\
\hline 7 & $6.6 \pm 0.75$ & $12.0 \pm 2.2$ & $7.5 \pm 1.1$ & $16 \pm 1.2$ & $<0.0001^{*}$ & $0.0002^{*}$ & $0.0002^{*}$ & $<0.0001^{*}$ \\
\hline 14 & $6.0 \pm 0.64$ & $8.1 \pm 1.8$ & $6.4 \pm 1.1$ & $7.4 \pm 0.74$ & $0.0084^{*}$ & $0.0371^{*}$ & 0.35 & $0.0418^{*}$ \\
\hline
\end{tabular}

- the highest mean is in the RV group; * achieved statistical significance 
Table 2. Lymphocyte percentage and p values for statistical comparison across groups.

\begin{tabular}{ccccccccc}
\hline \multirow{2}{*}{ Day } & \multicolumn{4}{c}{ LYM\% median (range) } & \multicolumn{5}{c}{ p value } \\
\cline { 2 - 9 } & C & SEP & SV & RV & C vs. SEP & SEP vs. SV & SEP vs. RV & SV vs. RV \\
\hline 1 & $70.3(12.8)$ & $51.9(25.5)$ & $59(38.4)$ & $69.8(27)$ & $<0.0001^{*}$ & 0.07 & $0.0005^{*}$ & 0.17 \\
\hline 4 & $65.5(17.5)$ & $42.8(27.2)$ & $55.6(31.3)$ & $44.5(20.3)$ & $0.0002^{*}$ & 0.09 & 0.61 & 0.14 \\
\hline 7 & $56.1(16.3)$ & $31.8(51.6)^{\star}$ & $44.9(43.9)^{\star}$ & $46(7.9)$ & $0.0383^{*}$ & 0.77 & 0.31 & 0.41 \\
\hline 14 & $55.3(22.2)$ & $53.3(20.5)$ & $55.8(25.1)$ & $55.1(4.5)$ & 0.46 & 0.81 & 0.96 & 0.78 \\
\hline
\end{tabular}

- Coefficient of variation $>30 \%$; * achieved statistical significance

\section{Lymphocyte percentage (LYM\%)}

We obtained differences between the $\mathrm{C}$ and SEP groups (except day 14) and one isolated difference between SEP and RV group in the first day (Figure 2) but no other difference between the studied groups was found. (Table 2)

\section{Procalcitonin (PCT)}

When comparing $C$ group with SEP one we recorded differences at all tested moments. The SV group compared to SEP showed a significant difference in day 1, day 4 and 7 but not day 14 . The RV and SEP groups showed no difference in day 1 , day 4 , or 14 but significant in day 7. Regarding the comparison between SV and RV, we found statistical difference in day 1 and 4 but no difference in day 7 and 14. (Table 3) (Figure 3)

\section{Interleukin 1-beta (IL-1B)}

When comparing $C$ group with SEP group we found significant difference for day 4, 7 and 14 but no difference in the first day. For the SEP and SV groups we found statistical difference for all studied moments with consistent lower means in the SV group. The RV group had consistent

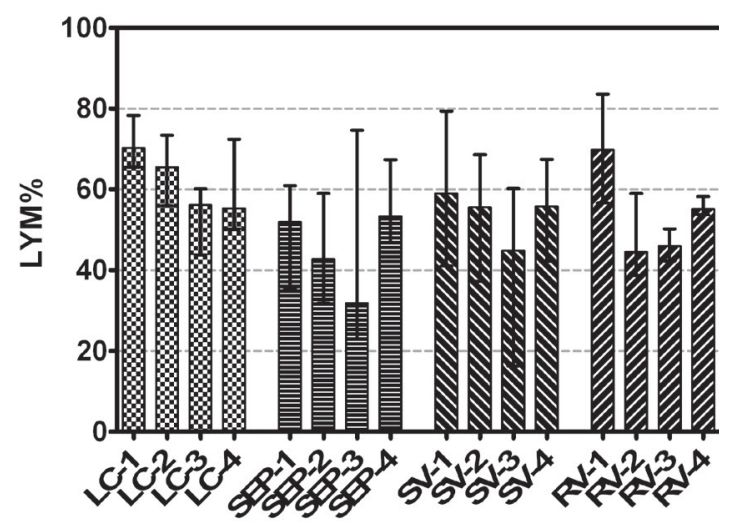

Figure 2. Lymphocyte percentage. (median and range)

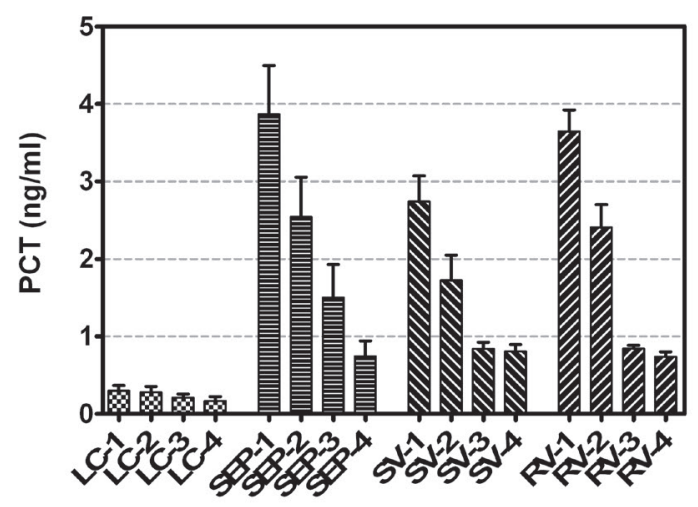

Figure 3. Procalcitonin. (median and range)

Table 3. Procalcitonin and p values for statistical comparison across groups.

\begin{tabular}{ccccccccc}
\hline \multirow{2}{*}{ Day } & \multicolumn{4}{c}{ PCT median (range) } & \multicolumn{4}{c}{$p$ value } \\
\cline { 2 - 9 } & C & SEP & SV & RV & C vs. SEP & SEP vs. SV & SEP vs. RV & SV vs. RV \\
\hline 1 & $0.305(0.171)$ & $3.77(1.73)$ & $2.79(0.91)$ & $3.68(0.77)$ & $<0.0001^{*}$ & $0.0005^{*}$ & 0.37 & $<0.0001^{*}$ \\
\hline 4 & $0.276(0.198)$ & $2.5(1.5)$ & $1.71(1.08)$ & $2.4(0.97)$ & $<0.0001^{*}$ & $0.0019^{*}$ & 0.53 & $0.0006^{*}$ \\
\hline 7 & $0.193(0.102)$ & $1.34(1.27)$ & $0.85(0.232)$ & $0.843(0.106)$ & $<0.0001^{*}$ & $0.0008^{*}$ & $0.0007^{*}$ & 0.96 \\
\hline 14 & $0.172(0.161)^{*}$ & $0.645(0.445)$ & $0.785(0.259)$ & $0.743(0.174)$ & $<0.0001^{*}$ & 0.43 & 0.94 & 0.09 \\
\hline
\end{tabular}

- Coefficient of variation $>30 \%$; achieved statistical significance 
Table 4. Interleukin 1 beta and p values for statistical comparison across groups.

\begin{tabular}{ccccccccc}
\hline \multirow{2}{*}{ Day } & \multicolumn{4}{c}{ IL-1 $\beta$ (mean \pm SD) } & \multicolumn{4}{c}{ p value } \\
\cline { 2 - 9 } & C & SEP & SV & RV & C vs. SEP & SEP vs. SV & SEP vs. RV & SV vs. RV \\
\hline 1 & $0.14 \pm 0.018$ & $0.168 \pm 0.036$ & $0.127 \pm 0.018$ & $0.391 \pm 0.061$ & 0.08 & $0.0127^{*}$ & $<0.0001^{*}$ & $<0.0001^{*}$ \\
\hline 4 & $0.108 \pm 0.014$ & $0.139 \pm 0.022$ & $0.105 \pm 0.019$ & $0.283 \pm 0.082$ & $0.0084^{*}$ & $0.0067^{*}$ & $0.0003^{*}$ & $<0.0001^{*}$ \\
\hline 7 & $0.105 \pm 0.018$ & $0.153 \pm 0.037$ & $0.11 \pm 0.02$ & $0.159 \pm 0.033$ & $0.0089^{*}$ & $0.0126^{*}$ & 0.73 & $0.0030^{*}$ \\
\hline 14 & $0.103 \pm 0.014$ & $0.129 \pm 0.009$ & $0.1 \pm 0.016$ & $0.158 \pm 0.033$ & $0.0008^{*}$ & $0.0007^{*}$ & $0.0321^{*}$ & $0.0006^{*}$ \\
\hline
\end{tabular}

* achieved statistical significance

higher means with statistical significance in day 1,4 and 14 . We also found statistical difference between SV and RV for all measurements. (Table 4) (Figure 4)

\section{Interleukin 6 (IL-6)}

We recorded differences for all studied moments when comparing $\mathrm{C}$ and SEP groups. Regarding SV group compared to SEP one, we found statistical difference in day 1 and 4 but not in day 7 and 14 . The RV group means were statistically different from SEP ones in day 1, 7 and 14 but no difference was noted in day 4 . The means from SV and RV differed significantly for the first three measurements (day 1, 4 and 7) but no difference was found in day 14. (Table 5) (Figure 5)

\section{Tumour Necrosis Factor - alpha (TNF- $\alpha)$}

We found obvious differences between $\mathrm{C}$ group and SEP for all measurements. Also the SV group showed smaller means than the SEP ones with significant differences for all four measurements (day 1, 4, 7 and 14). In the RV group, only in day 4 and 7 TNF- $\alpha$ levels were significantly lower, while day 1 and day 14 lev-

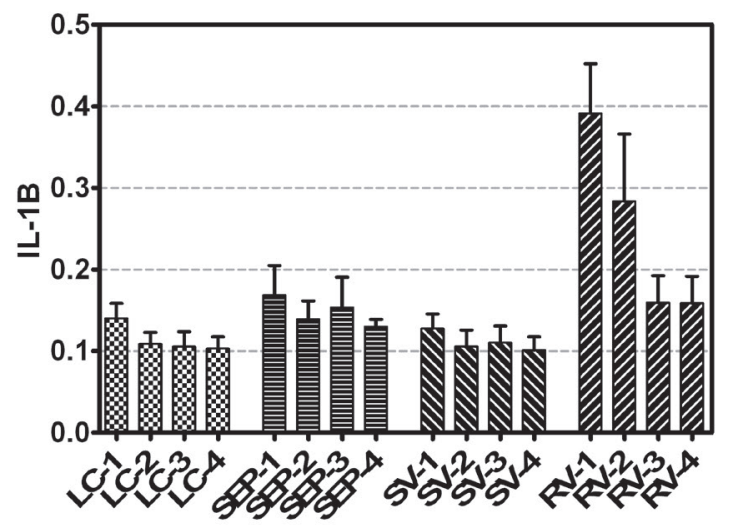

Figure 4. Interleukin 1beta. (mean and SD)

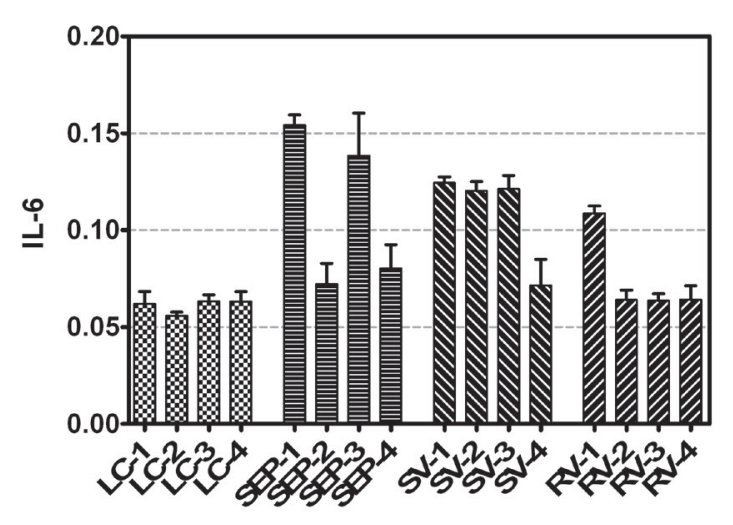

Figure 5. Interleukin 6. (mean and SD)

Table 5. Interleukin 6 and $p$ values for statistical comparison across groups.

\begin{tabular}{ccccccccc}
\hline \multirow{2}{*}{ Day } & \multicolumn{4}{c}{ IL-6 (mean \pm SD) } & \multicolumn{3}{c}{ p value } \\
\cline { 2 - 8 } & C & SEP & SV & RV & C vs. SEP & SEP vs. SV & SEP vs. RV & SV vs. RV \\
\hline 1 & $0.062 \pm 0.006$ & $0.154 \pm 0.005$ & $0.125 \pm 0.002$ & $0.109 \pm 0.003$ & $<0.0001^{*}$ & $<0.0001^{*}$ & $<0.0001^{*}$ & $<0.0001^{*}$ \\
\hline 4 & $0.055 \pm 0.001$ & $0.072 \pm 0.01$ & $0.12 \pm 0.004$ & $0.064 \pm 0.005$ & $0.0017^{*}$ & $<0.0001^{*}$ & 0.07 & $<0.0001^{*}$ \\
\hline 7 & $0.063 \pm 0.003$ & $0.139 \pm 0.021$ & $0.121 \pm 0.007$ & $0.063 \pm 0.003$ & $<0.0001^{*}$ & 0.05 & $<0.0001^{*}$ & $<0.0001^{*}$ \\
\hline 14 & $0.063 \pm 0.005$ & $0.08 \pm 0.012$ & $0.071 \pm 0.013$ & $0.064 \pm 0.007$ & $0.0041^{*}$ & 0.18 & $0.0057^{*}$ & 0.19 \\
\hline
\end{tabular}

* achieved statistical significance 
Table 6. Tumour Necrosis Factor -alpha and p values for statistical comparison across groups.

\begin{tabular}{ccccccccc}
\hline \multirow{2}{*}{ Day } & \multicolumn{4}{c}{ TNF- $\alpha(\operatorname{mean} \pm$ SD) } & \multicolumn{5}{c}{$\mathrm{p}$ value } \\
\cline { 2 - 9 } & $\mathrm{C}$ & SEP & SV & RV & C vs. SEP & SEP vs. SV & SEP vs. RV & SV vs. RV \\
\hline 1 & $0.131 \pm 0.003$ & $0.43 \pm 0.042$ & $0.177 \pm 0.048$ & $0.389 \pm 0.061$ & $<0.0001^{*}$ & $<0.0001^{*}$ & 0.14 & $<0.0001^{*}$ \\
\hline 4 & $0.106 \pm 0.021$ & $0.414 \pm 0.035$ & $0.137 \pm 0.017$ & $0.269 \pm 0.065$ & $<0.0001^{*}$ & $<0.0001^{*}$ & $<0.0001^{*}$ & $<0.0001^{*}$ \\
\hline 7 & $0.099 \pm 0.025$ & $0.339 \pm 0.071$ & $0.124 \pm 0.014$ & $0.159 \pm 0.033$ & $<0.0001^{*}$ & $<0.0001^{*}$ & $<0.0001^{*}$ & $0.0171^{*}$ \\
\hline 14 & $0.094 \pm 0.014$ & $0.147 \pm 0.03$ & $0.091 \pm 0.008$ & $0.157 \pm 0.033$ & $0.0011^{*}$ & $0.0002^{*}$ & 0.54 & $<0.0001^{*}$ \\
\hline
\end{tabular}

* achieved statistical significance

els did not differ significantly from SEP group. Directly comparing SV and RV groups showed significantly differences for all measurements. (Table 6) (Figure 6)

\section{Discussions}

\section{The sepsis model}

As we decided to use a previously described murinic sepsis model (25), this study did not focus on proving septic state of the animals as required by present definition of sepsis (1). Nonetheless, we showed significant differences between the control group (C) who received the sham operation and the sepsis group (SEP) to whom caecal ligation and puncture technique was applied.

The SEP group had a higher white blood cell count (WBC) during the whole studied period. Also lymphocyte percentage (LYM\%) was smaller for the SEP group but in the context of a higher total blood cell count we may safely assume that the WBC count rose on behalf of the polymorphonuclear cells (PMN) as a response to the infectious injury.

Procalcitonin (PCT) levels differed with a mean of $0.297 \mathrm{ng} / \mathrm{ml}$ for C group and $3.87 \mathrm{ng} / \mathrm{ml}$ for SEP group (values for day $1, p<0.05$ ) (Figure $3)$. The studied interleukin levels were also higher for the SEP group. Regarding IL-1 $\beta$ and IL-6 we have noticed an increase in mean values for the SEP group in day 7 compared with previous determinations (from day 4) (Figure 4 and 5). This difference is less obvious for IL- $1 \beta$ but of a greater magnitude for IL- 6 levels. TNF- $\alpha$ and

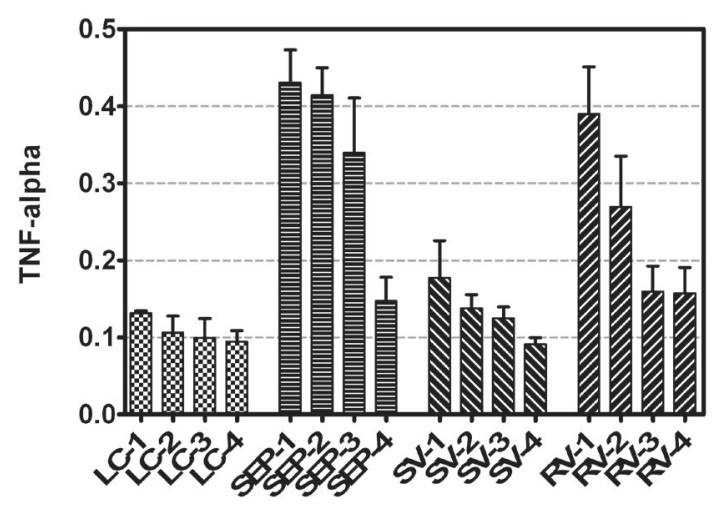

Figure 6. Tumour Necrosis Factor - alpha. (mean and SD)

PCT did not showed such behaviour. The data we have collected suggest that between day 4 and 14 there is a new peak for IL- 6 and IL- $1 \beta$ blood levels. This only happens for the statin treated groups.

\section{Statins effect on CLP-induced sepsis}

In order to evaluate the effect of the administered statins, we compared the SEP group to the $\mathrm{SV}$ or RV one.

Regarding WBC count, we encountered slightly different effects for SV and RV. In the first day both statins had a lowering effect on WBC counts. In day 4 we found higher counts compared to day 1 (a rising in WBC number that was not present in the SEP group). By day 7 the number of WBC dropped significantly for SV but almost doubled for the RV group (Figure 1). In day 14 we found similar values for SV and $\mathrm{RV}$, both lower than the SEP group. Lymphocyte 
percentage did not differ across these groups (Figure 2) so we concluded that any significant difference in WBC count was caused by granulocytes.

Regarding PCT blood concentration, when compared with SEP, we observed lower values for the SV group ( $p=0.0005)$ from the first day but no difference for the RV group ( $p=0.37$ ). PCT values in the SV group remained lower throughout the entire experiment whereas in the RV group the only difference observed was in day 7 when PCT mean value was the same as the one in SV group (and significantly lower than the SEP group) (Figure 3). In day 14 there was no difference between the three groups.

IL-1 $\beta$ levels were lower in SV group (mean values were close to those observed in C group) but significant higher levels were recorded for the RV group. (Figure 4)

Both Simvastatin and Rosuvastatin had a clear effect on IL-6 levels compared to SEP group. Both SV and RV groups showed smaller levels in day 1 . By day 4 there was no difference in the RV group but the SV group showed increased levels. In day 7 the rise in IL-6 levels observed in the SEP group was not matched in any of the other groups. By day 14 no difference was noted between the three groups.

Regarding TNF- $\alpha$, Simvastatin showed a higher impact resulting in lower levels compared with SEP group. In the RV group we had no difference in day 1 but the levels started to drop by day 4. Even if this lowering effect was smaller than in SV group, the differences were significant $(p<0.0001$ for day 4 and 7). (Figure 6)

\section{Which statin?}

To assess the differences between the effect of the two statins (Simvastatin and Rosuvastatin) on our CLP-induced sepsis model we compared the mean values for all the studied parameters.

Regarding white blood cells we found higher counts in the SV group for the first 4 days (in day 1 these differences were not statistically significant; $p=0.054$ ) (Figure 1) but in day 7 we observed a drastic increase in WBC for the RV group. This increase was not matched by the SV group (Figure 1).

No differences were found regarding lymphocyte percentage (LYM\%). (Figure 2)

PCT had smaller values the first 4 days in SV group. By day 7 the recorded values for the two groups were similar. (Figure 3)

IL-1 $\beta$ values differed significantly among the two groups. Consistent smaller values were recorded for the $\mathrm{SV}$ one for all four measurements. (Figure 4)

For IL-6 we showed smaller values for RV. The differences were significant for all but day 14. (Figure 5)

TNF- $\alpha$ levels were higher for the RV group with statistical significance for all measurements. (Figure 6)

\section{Statins vs. corticosteroids}

Both type of drugs have similar anti-inflammatory, immunomodulatory, anti-oxidant, anti-thrombotic and protective vascular endothelial effects with small differences among each action. What actually makes these two therapeutic approaches different is the time needed for the onset of their effect. The anti-inflammatory effects of corticosteroids can be observed within 24 hours, whereas statins achieved measurable anti-inflammatory effect only after 7 to 14 days of treatment as shown by some studies using human subjects $(39,40)$. This delayed effect seem to make statins an unsuitable candidate for systemic inflammation suppression during the acute phase of sepsis $(17,41)$. However the last guidelines offered by Sepsis Surviving Champaign (1) issued a strong recommendation that corticosteroids should not be used for the treatment of sepsis or septic shock (unless hemodynamic stability could not be achieved by the use of fluid resuscitation and vasopressors). 


\section{Summary}

When looking at the whole array of data we noticed that PCT, IL- $1 \beta$ and TNF- $\alpha$ levels were lower for the Simvastatin treated group. Also the level of IL- $1 \beta$ for the Rosuvastatin treated group was higher than the one found in the not-treated sepsis group (SEP). TNF- $\alpha$ level after treatment with Rosuvastatin was similar with the one found in SEP group. All this suggests that Simvastatin has a greater anti-inflammatory effect compared to Rosuvastatin. Moreover, Rosuvastatin could induce a paradoxical pro-inflammatory effect (IL-1 $\beta$ level higher in RV group compared to SEP). Even so, the level of IL-6 in day 1 was lower for RV group, dropped significantly by day 4 and remained at this level. In contrast the Simvastatin treated group showed higher initial levels that remained the same at least for the first seven days. IL- 6 is considered a major marker of sepsis and a prognosis factor $(28,41)$. For this study the animals were monitored for 14 days. During this time no subject died so mortality could not be evaluated.

\section{Limitations}

The major limitation of the study consists in the relative wide period of time between measurements. This only made available a few snapshots of the actual immunologic activity during sepsis with the possibility of missing some of the rapid modifications that would take place in between measurements. Also the number of subjects used caused a high degree of heterogeneity which resulted in a variation coefficient over $30 \%$ for some of the measurements. Because of the high complexity of the immunological response future research should monitor a larger number of inflammation markers.

\section{Conclusion}

We conclude that both drugs showed anti-inflammatory effects on the murinic CLP-induced sepsis model. Between the two, Simvastatin had a greater impact on lowering blood levels of established pro-inflammatory markers. Moreover, Rosuvastatin seem to have a paradoxical pro-inflammatory effect suggested by the increased levels of IL-1 $\beta$ (RV vs. SEP). Even if both Simvastatin and Rosuvastatin caused lower levels of IL-6 compared with non-treated septic subjects, relatively higher levels of IL-6 were detected in SV group compared with RV.

\section{Acknowledgements and financial support}

The authors would like to extend our gratitude to Mr. Gheorghe Bărbat and Mr. Ioan Precup for their help in managing the animal subjects, and also to Dr. Floredana Șular for her help with laboratory testing. Special thanks to Dr. Natalia Hagău for excellent advice and support before and throughout the experiment.

This paper is partly supported by the Sectorial Operational Programme Human Resources Development (SOP HRD), financed from the European Social Fund and by the Romanian Government under the contract number POSDRU 80641.

This project was partly financed by internal research grants at the University of Medicine and Pharmacy from Tîrgu Mureș, Romania (CIGCS 20/11.12.2013).

\section{References}

1. Dellinger RP, Levy MM, Rhodes A, Annane D, Gerlach H, Opal SM, et al. Surviving sepsis campaign: international guidelines for management of severe sepsis and septic shock: 2012. Crit Care Med. 2013 Feb;41(2):580 637. DOI: 10.1097/CCM.0b013e31827e83af

2. Angus DC, Linde-Zwirble WT, Lidicker J, Clermont G, Carcillo J, Pinsky MR. Epidemiology of severe sepsis in the United States: analysis of incidence, outcome, and associated costs of care. Crit Care Med. 2001 Jul;29(7):1303-10. DOI: 10.1097/00003246200107000-00002

3. Kruger P, Venkatesh B. Are There any Benefits from Statin Treatment for the Septic Patient? Curr Athero- 
scler Rep. 2014 Jan;16(1):378. DOI: 10.1007/s11883013-0378-9

4. Terblanche M, Almog Y, Rosenson R. Statins and sepsis: multiple modifications at multiple levels. Lancet Infect Dis. 2007;7(May):358-68. DOI: 10.1016/ S1473-3099(07)70111-1

5. Liao J, Laufs U. Pleiotropic effects of statins. Annu Rev Pharmacol Toxicol. 2005 Jan;45:89-118. DOI: 10.1146/annurev.pharmtox.45.120403.095748

6. Radigan KA, Urich D, Misharin A V, Chiarella SE, Soberanes S, Gonzalez A, et al. The effect of rosuvastatin in a murine model of influenza A infection. PLoS One. 2012 Jan;7(4):1-10. DOI: 10.1371/journal. pone. 0035788

7. Araújo-Filho I, Jácome DT, Rêgo ACM, Azevedo IM, Egito EST, Medeiros AC. Effect of the simvastatin in abdominal sepsis of diabetic rats. [Efeito da sinvastatina na sepse abdominal de ratos diabéticos]. Rev Col Bras Cir. 2010 Feb;37(1):39-44. DOI: 10.1590/S010069912010000100009

8. Almeida JL, Sampietre SN, Mendonça Coelho AM, Trindade Molan NA, Machado MCC, Monteiro da Cunha JE, et al. Statin pretreatment in experimental acute pancreatitis. J Pancreas. 2008 Jan;9(4):431-9.

9. Alvarez de Sotomayor M, Vega S, Mingorance C, Marhuenda E, Herrera MD. Effects of HMG-CoA reductase inhibition by simvastatin on vascular dysfunction induced by lipopolysaccharide in rats. Pharmacology. 2008 Jan;82(2):89-96. DOI: 10.1159/000135629

10. Hinz J, Gehoff P, Schotola H, Hosseini MT, Didilis VN, Jebran AF, et al. Hemodynamic effects of peri-operative statin therapy in on-pump cardiac surgery patients. J Cardiothorac Surg. 2012 Jan;7:39. DOI: 10.1186/17498090-7-39

11. Al Harbi SA, Tamim HM, Arabi YM. Association between statin therapy and outcomes in critically ill patients: a nested cohort study. BMC Clin Pharmacol. 2011;11(12):1-7.

12. Christensen S, Thomsen RW, Johansen MB, Pedersen L, Jensen R, Larsen KM, et al. Preadmission statin use and one-year mortality among patients in intensive care - a cohort study. Crit Care. 2010 Jan;14(2):R29. DOI: $10.1186 / \mathrm{cc} 8902$

13. Khan A, Yeung D, Wyatt B, Rafai T, Byant J, Coates A, et al. Effects of statins on postoperative sepsis, systemic inflammatory response syndrome and mortality after colorectal surgery. Crit Care. 2009;13(Suppl 4):P47. DOI: $10.1186 / \mathrm{cc} 8103$

14. Thomsen RW, Hundborg HH, Johnsen SP, Pedersen L, Sørensen HT, Schønheyder HC, et al. Statin use and mortality within 180 days after bacteremia: a population-based cohort study. Crit Care Med. 2006 Apr;34(4):1080-6. DOI: 10.1097/01. CCM.0000207345.92928.E4

15. McAuley DF, Laffey JG, O'Kane CM, Cross M, Per- kins GD, Murphy L, et al. Hydroxymethylglutaryl-CoA reductase inhibition with simvastatin in acute lung injury to reduce pulmonary dysfunction (HARP-2) trial: study protocol for a randomized controlled trial. Trials. 2012 Jan;13(1):170. DOI: 10.1186/1745-6215-13-170

16. Novack V, Eisinger M, Frenkel A, Terblanche M, Adhikari NKJ, Douvdevani A, et al. The effects of statin therapy on inflammatory cytokines in patients with bacterial infections: a randomized double-blind placebo controlled clinical trial. Intensive Care Med. 2009 Jul;35(7):1255-60. DOI: 10.1007/s00134-009-1429-0

17. Kruger PS, Harward ML, Jones M a, Joyce CJ, Kostner KM, Roberts MS, et al. Continuation of statin therapy in patients with presumed infection: a randomized controlled trial. Am J Respir Crit Care Med. 2011 Mar 15;183(6):774-81. DOI: 10.1164/rccm.201006-0955OC

18. Patel JM, Snaith C, Thickett DR, Linhartova L, Melody T, Hawkey P, et al. Randomized double-blind placebo-controlled trial of $40 \mathrm{mg} /$ day of atorvastatin in reducing the severity of sepsis in ward patients (ASEPSIS Trial). Crit Care. 2012 Dec 11;16(6):R231. DOI: 10.1186/cc11895

19. Kruger P, Bailey M, Bellomo R, Cooper DJ, Harward M, Higgins A, et al. A multicenter randomized trial of atorvastatin therapy in intensive care patients with severe sepsis. Am J Respir Crit Care Med. 2013 Apr;187(7):743-50. DOI: 10.1164/rccm.201209-17180C

20. Craig TR, Duffy MJ, Shyamsundar M, McDowell C, O'Kane CM, Elborn JS, et al. A randomized clinical trial of hydroxymethylglutaryl- coenzyme a reductase inhibition for acute lung injury (The HARP Study). Am J Respir Crit Care Med. 2011 Mar 1;183(5):620-6. DOI: 10.1164/rccm.201003-0423OC

21. Woerndle RH, Maxwell DL. Statins and sepsis: good bullet, disappearing target. J Am Osteopath Assoc. 2008 Sep;108(9):486-90.

22. O'Kane C. Statins and Sepsis: Potential Benefit but More Unanswered Questions. Am J Respir Crit Care Med. 2013;187:672-5. DOI: 10.1164/rccm.201212-2305ED

23. JR JCMS. Can statins improve outcome in colorectal surgery? Part I. J Coloproctology (Rio Janeiro). 2012;334-8.

24. Gao F, Linhartova L, Johnston AM, Thickett DR. Statins and sepsis. Br J Anaesth. 2008 Mar 1;100(3):288-98. DOI: $10.1093 / \mathrm{bja} / \mathrm{aem} 406$

25. Toscano MG, Ganea D, Gamero AM. Cecal ligation puncture procedure. J Vis Exp. 2011 Jan;(51):1-5.

26. Hubbard WJ, Choudhry M, Schwacha MG, Kerby JD, Rue LW, Bland KI, et al. Cecal ligation and puncture. Shock. 2005 Dec;24 Suppl 1:52-7. DOI: 10.1097/01. shk.0000191414.94461.7e

27. Wichterman KA, Baue AE, Chaudry IH. Sepsis and 
septic shock--a review of laboratory models and a proposal. J Surg Res. 1980 Aug;29(2):189-201. DOI: 10.1016/0022-4804(80)90037-2

28. Jekarl DW, Lee S-Y, Lee J, Park Y-J, Kim Y, Park JH, et al. Procalcitonin as a diagnostic marker and IL-6 as a prognostic marker for sepsis. Diagn Microbiol Infect Dis. 2013 Feb 4;75(4):342-7. DOI: 10.1016/j.diagmicrobio.2012.12.011

29. Lee H. Procalcitonin as a biomarker of infectious diseases. Korean J Intern Med. 2013 May;28(3):285-91. DOI: $10.3904 / \mathrm{kjim} .2013 .28 .3 .285$

30. Faix JD. Biomarkers of Sepsis. Crit Rev Clin Lab Sci. 2013;50(1):23-36. DOI: $10.3109 / 10408363.2013 .764490$

31. European Union. Directive 2010/63/EU Of The European Parliament And Of The Council of 22 September 2010 on the protection of animals used for scientific purposes. Off J Eur Union. 2010;33-79.

32. University of California. Guidelines for Anesthesia and Analgesia in Laboratory Animals. 2012. p. 1-5.

33. Merx MW, Liehn E a, Janssens U, Lütticken R, Schrader J, Hanrath P, et al. HMG-CoA reductase inhibitor simvastatin profoundly improves survival in a murine model of sepsis. Circulation. 2004 Jun 1;109(21):25605. DOI: 10.1161/01.CIR.0000129774.09737.5B

34. French E, Vandewoude S, Granowski J, Maul D. Assessment of pain in laboratory animals. Contemp Top. 2000;39(85).

35. Leach M. Pain assessment in laboratory animals using behaviour and facial expressions. 2011.
36. Sotocinal SG, Sorge RE, Zaloum A, Tuttle AH, Martin LJ, Wieskopf JS, et al. The Rat Grimace Scale: a partially automated method for quantifying pain in the laboratory rat via facial expressions. Mol Pain. 2011 Jan;7(1):55. DOI: 10.1186/1744-8069-7-55

37. Giusti-Paiva A, Martinez MR, Felix JVC, da Rocha MJA, Carnio EC, Elias LLK, et al. Simvastatin decreases nitric oxide overproduction and reverts the impaired vascular responsiveness induced by endotoxic shock in rats. Shock. 2004 Mar;21(3):271-5. DOI: 10.1097/10. shk.0000115756.74059.ce

38. Leary S, Underwood W, Anthony R, Cartner S. AVMA Guidelines for the Euthanasia of Animals: 2013 Edition [Internet]. 2013.

39. Hernandez TL, Capell WH, Wolfe P, Gerard LA, Eckel RH. Time course of C-reactive protein reduction with simvastatin therapy in patients with type 2 diabetes mellitus. Am J Cardiol. 2006 Dec 15;98(12):1656-9. DOI: 10.1016/j.amjcard.2006.07.047

40. Plenge JK, Hernandez TL, Weil KM, Poirier P, Grunwald GK, Marcovina SM, et al. Simvastatin lowers C-reactive protein within 14 days: an effect independent of low-density lipoprotein cholesterol reduction. Circulation. 2002 Oct 17;106(12):1447-52. DOI: 10.1161/01.CIR.0000029743.68247.31

41. Yende S, Milbrandt E, Kellum J. Understanding the potential role of statins in pneumonia and sepsis. Crit Care Med. 2011;39(8):1871-8. DOI: 10.1097/ CCM.0b013e31821b8290 